\title{
AN ANLAYSIS OF ENGLISH PASSIVE SENTENCE TRANSLATION INTO INDONESIAN
}

\author{
Ni Putu Meri Dewi Pendit \\ Program Studi Sastra Inggris Bidang Minat Penerjemahan, Universitas Terbuka \\ Email:putumeri@ecampus.ut.ac.id
}

\begin{abstract}
ABSTRAK
Konstruksi kalimat aktif dan pasif umumnya digunakan dalam bahasa Inggris dan bahasa Indonesia. Kalimat pasif adalah bentuk kalimat yang menekankan pada orang atau objek yang mengalami tindakan daripada orang atau objek yang melakukan tindakan. Kalimat pasif dalam bahasa Inggris ditandai oleh bentuk to be+ past participle. Dan kalimat pasif lainnya dibentuk dengan infinitif dan gerund. Kalimat pasif bahasa Indonesia ditandai dengan adanya awalan di-, ter-, dan ke an pada predikatnya. Tujuan dari penelitian ini adalah 1) untuk mengidentifikasi terjemahan kalimat pasif bahasa Inggris ke dalam bahasa Indonesia, dan 2) untuk menemukan pergeseran terjemahan yang terjadi dari kalimat pasif bahasa Inggris ke bahasa Indonesia. Penelitian ini menggunakan metode kualitatif. Data diambil dari novel karya Stephenie Meyer (2008) berjudul Breaking Dawn dan terjemahannya dalam bahasa Indonesia. Hasil penelitian menunjukkan bahwa tidak semua kalimat pasif bahasa Inggris juga diterjemahkan ke dalam kalimat pasif dalam bahasa Indonesia. Beberapa di antaranya diterjemahkan ke dalam kalimat aktif.
\end{abstract}

Kata kunci: Kalimat aktif, kalimat pasif, pergeseran terjemahan

\begin{abstract}
Active and passive sentence constructions are commonly used both in English and in Indonesian. The passive sentence is a form of sentence which emphasizes on the person or object that experiences the action rather than the person or object that performs the action. The passive sentence in English is formed by to be + past participle. And the others passive sentences are formed with infinitive and gerund. The Indonesian passive sentences are caractherized by the use of prefix $d i-$, ter-, and $k e--a n$ in the predicate. The objectives of this study are 1) to identify the translation of English passive sentences in Indonesian, and 2) to find the translation shift that occurs from the English passive sentences into Indonesian. This research uses qualitative method. The data is taken from a novel written by Stephenie Meyer (2008) entitled Breaking Dawn and its translation in Indonesian. The result shows that not all of the English passive sentences are translated into Indonesian passive sentences. Some of them are translated into Indonesian active sentences.
\end{abstract}

Keywords: Active sentences, passive sentences, translation shift

\section{INTRODUCTION}

People can find many reasons of why learning a new language is a good idea. It allows the learner to communicate with people from different country or to have better understanding to a diffent culture. It has been a long time ago people around the wold have a mission to learn English as it has become an international language. When this mission has been successful, people start to learn the other most spoken language in the world. Indonesia as the world's largest island country which is ready to have a big role around the globe brings learning Indonesian language or Bahasa Indonesia more important.

BIPA (Bahasa Indonesia untuk Penutur Asing - Indonesian Language for Foreigners) is design to equip participants with the ability to use standard Indonesian language. During the teaching and learning process, teachers of BIPA find difficulties in giving an overview or explaining about active and passive 
sentences of Bahasa Indonesia. Teachers of BIPA may found many exceptions in Indonesian sentence construction while foreign learners are used to belive that there are always reasons to any language contructions. The Indonesian word which begins with the letters $k, p, t$, or $s$ will be dissolved if the word is added with prefix meng- or peng-. For example: karang becomes mengarang, pungut becomes memungut, and both them are used as active verbs in Indonesian active sentences. In order to construct the passive sentences, the root word is added by prefix di- (dipungut, ditolong). In the other hand, can the same case be applied to the word pesona? The root word pesona comes from the letter / $\mathrm{p} /$. According to the rules above, this word should become memesona but not mempesona. However, many people disagree with this rule because it feels so weird. It also leads to another question 'Can the word memesona become dipesona in passive construction?' Due to these examples, a study about translation of English passive sentences into Indonesian is really needed.

In both English and Indonesian, passive sentences are commonly made without referring to the agent of an action; it probably due to the unknown or unimportant agent. Despite of not reffering to an agent, the passive sentences can also be added by a mention of an agent using by in English or oleh at the end of Indonesian sentences which is different from the active sentences, where the agent is the subject that precedes the verb (Wikipedia, 2021). The characteristic of English passive sentences is constructed by 'to be + past participle'. And the others passive sentences are formed with infinitive and gerund (Murphy, Raymond; Altman, 1992). According to Hasan Alwi, et al (2008), the Indonesian passive sentences are caractherized by the use of prefix $d i-, t e r-$, and $k e--a n$ in the predicate.

A study on the translation of English passive sentences was conducted by Kamayana (2015). He studied on the equivalent of English passive sentences into Indonesian and focused his study on one type of English passive construction (to be + past participle). He found that most of the English passive sentences are also translated in the form of Indonesian passive sentences. In the other hand, there are still some other forms of English passive sentences which have not been analysed how they were translated into Indonesian.

Due to the fact above, an analysis on the translation of English passive sentences into Indonesian is still needed. Moreover, being a language teacher or a translator needs to be able to master both English and Indonesian language. It will enable them to master English as the source language and Indonesian as the target language or vice versa. In other words, able to understand the source language well will lead them to be able to express ideas in the target language. Hopefully, the result of this study may overcome problems related with passive sentences in English and Indonesian faced by translator and especially teacher of BIPA.

\section{METHODS}

Qualitative method is used in this study. The categories and conclusion are found after the analysis of the data collected. The data is collected through novels observation on the translation of English passive sentences into Indonesian. In order to answer the problems of the study, the procedures of data collection 
are: reading the whole content of the novel, identifying passive sentences in English version novel, identifying the translation of the English passive sentences in Indonesian version novel, and put the data side by side into a list.

The writer uses an English novel as Source Language (SL) Breaking Dawn by Stephanie Meyer (2008) and its Indonesian translation (TL) Awal yang Baru that was translated by Monica Dwi Chresnayani (2009). The novels consist of 39 chapters. The original novel consists of 754 pages. And there are 864 pages on the Indonesian version. These novels were chosen to be analyzed due to lots of variations on the translation of English passive sentences into Indonesian.

\section{RESULTS AND DISCUSSIONS}

In addition to translating general book very well, novel translators should equip themselves with excellent writing skills. A novel translation could be said to be "halfcomposing." Even using new translation method, a novel translator should be so good at processing the words that the readers could be carried away to enjoy the novel they read. Generally, the language used by the novelist is typical, and it is different between one author and others.

$S L$

He didn't comment so a few seconds later I asked, "Am I forgiven?"

The above sentence is passive sentence. Its pattern is constructed in the form of to be (am) + past participle. It belongs to simple presents tense. The passive construction of the TL in Indonesian language is by attaching prefix
The novel translator should be able to follow the original author's language style. Thus, the reader could easily see and read the uniqueness of the work. Even using new procedure of translaion, the point is not simply to translate. The translator should translate many words in Source Language (SL) that probably do not have direct equivalence in Target language (TL). Here, an excellent writing skill is badly needed by the translator.

The result of the English passive sentence translation in the novel Breaking Dawn indicated two possible translations. First, the English passive sentences remain passive in Indonesian. Second, the English passive sentences become active sentences in Indonesian. The second form of translation can not be avoided. It is done in order to make the result of the translation more acceptable in Indonesian.

The first identification of the English passive sentences translation is in the form of passive sentences in Indonesian language. It was found 125 passive sentences from the 39 chapter of the novel. From thoses sentences, most of the construction of the passive sentences is to be + past participle. The following is one of the sentences in simple present tense (is/am/are + past participle).

\section{$T L$}

Edward tidak berkomentar, jadi beberapa detik kemudian aku bertanya, "Apakah aku dimaafkan?"

$d i$ - to the root word. It is an appropriate equivalent of the SL to the TL. It translated instantly prom passive to passive in Indonesian language. The form of passive sentences to be (was/were) + past participle is mostly found in the 
Jurnal Santiaji Pendidikan, Volume 11, Nomor 3, September 2021 ISSN 2087-9016, e-ISSN 2685-4694

novel. The to be here is in simple past tense becoming was/were. The followings

$S L$

The little crowd spread out under the soft shine of the twinkle lights, and we were greeted again by the friends we'd just embraced

Dark blue sapphires were clustered into intricate floral shapes atop the teeth

It was smoothed into sleek pin curls around her pixie face

The passive sentences above can clearly be seen that there is process of syntax. To be (was/were) + past participle was translated by attaching prefix $d i$ - to the root word. It is from were + greeted to $d i-+$ sambut. Passive sentences in simple past tense were just simply translated into lexis. Both of the SL and the TL are using transitif verbs. It is only on the first sentence, the agent is mentioned which is

$S L$

Esme was troubled by the hardships this is putting your pack through.

Like always, as soon as I started thinking about Edward I was caught up in a dizzy spin of fantasies.

The actions verbs in the SL above are happened accidentally, unintendedly, or suudenly. The verbs are involuntary actions. Hence, they are correctly translated by attaching prefix ter- to the root word. Was trouble is translated to terganggu, and was caught is translated to terperangkap. If those were attached by prefix $d i$-, the meaning of the sentence would be misinterpreted. Prefix $d i$ - refers are some example of the passive construction in simple past tense.

\section{$T L$}

Kerumunan kecil menyebar di bawah temaram lampu yang berkelap-kelip, dan kami disambut lagi oleh teman-teman yang tadi memeluk kami

Batu-batu safir bitu dirangkai membentuk desain bunga rumit di atasnya

Rambutnya disisir mengikal di sekeliling wajah mungilnya.

indicated by the word by - oleh, whereas the second and the third examples do not mention the agent that precedes the verb.

The other Indonesian prefix used to translate English passive sentences in the novel is ter-. This prefix is attached to the verbs because the SL sentence is intransitive sentence. The followings are the data using prefix ter- + Indonesian verb as its translation.

\section{$T L$}

Namun Esme merasa terganggu karena kesulitan yang dialami kawananmu.

Seperti biasa, begitu mulai memikirkan Edward, aku langsung terperangkap dalam fantasifantasi yang memusingkan.

to passive sentence with deliberate action and prefix ter-refers to accidental action.

The passive form of sentences in SL is also in past perfect tense. The construction is had + been + past participle. Like passive in simple past tense above, English passive sentences in past perfect tense is also translated into Indonesian passive sentence. In sorth, the passive in SL is also translated into passive in TL. 
The prefx $d i$ - and ter- are still applied. The

$S L$

1. Who had been dispatched to pick up my mother and her husband, Phil, from their hotel

2. Our vows were the simple, traditional words that had been spoken a million times

3. She had been raised in the tradition of her people.

4. Every cell in my body had been razed to ash

5. Some instinct to defend had been triggered, and I automatically searched for any sign of danger

6. When I'd been forced to admit that the truck had become no more than a still-life tribute to classic Chevys on my curb.

The data above indicates that passive in the SL is also passive in the TL. The different are only on the prefix attached to the Indonesian verbs. Sentences from number 1 until 3 are deliberate actions. The deliberate action in Indonesian is commonly indicated by prefix me-. On the contrary, the prefix $d i$ - is used to make the passive form of an active verb me-. Therefore, the best equivalent is by the addition of prefix $d i$ - to the root verb. Data on number 2 and 3 are using confix di$k a n$. Confix di-kan is one of the kinds of affixes that function to form passive verbs. The meanings of this confix are stating causative meaning or causing something to happen, and stating the meaning of an action done for someone else. There is a

SL

That the creature must be killed immediately

We're protecting those who should be protected. following data is the examples.

$T L$

Yang dikirim untuk menjemput

ibuku dan suaminya, Phil, dari

hotel tempat mereka menginap

Janji setia kami sederhana, kata-

kata tradisional yang sudah

diucapkan jutaan kali

Dia dibesarkan dalam tradisi

masyarakatnya.

Setiap sel tubuhku sudah terbakar

habis menjadi abu

Ada insting pertahan diri yang

terpicu, dan aku otomatis mencari

pertanda adanya bahaya

Ketika aku terpaksa mengakui

trukku sudah berubah jadi tugu

peringatan bagi Chevy klasik di

punggir jalan depan rumahku.

causative meaning on data number 2 above... had been spoken is translated to sudah diucapkan. Meanwhile, the confix di-kan on data number 3 does not mean causing something to happen. The meaning of $d i$ - kan here refers to an action done for someone, but in the data above the agent is not mentioned. The data number 3 until 6 uses prefix ter-. As explained above, this prefix indicates that the action verb is happened unintendedly.

The other form of passive sentences found in the SL is modal + be + past participle. The modal is a type of auxiliary verb that is used to express: ability, posibility, permission, or obligation. The followings are the two examples data.

$T L$

Bahwa makhluk itu harus segera dibunuh.

Kami melindungi mereka yang seharusnya dilindungi. 
The first sentence implies a meaning of necessity or requirement. And the second sentence idicates an offer of a polite suggesstion. The person who stating it is quite sure (a positive answer). The use of prefix $d i$ - found in the TL as the result of SL passive sentence translation dominates the result of translation. In the translation from passive to passive, prefix $d i$ - and ter- should be used correctly. Therefore, the meaning of the source language would meet its best translation in the target language.

The second type of translation found in the novel is pasive to active translation. The passive sentences in SL are translated

\section{$S L$}

Jacob was determined to come with us

I am disappointed that Alice didn't make sure you were forced to look in a mirror

Prefix ber- in Indonesian language is used to form verb and adjective. The data found in this study indicates that the prefix ber- is used to form an active verb. According to Hasan Alwi, et al (2008), prefix ber- means being something, having something, or having a certain attribute. The verbs created with prefix ber- indicates intransitive verb. Intransitive verb is verb which does not need any object or complement to complete the meaning of the sentence. It is already perfect and the meaning can be easily understood. And verb with prefix ber- is always an active verb. It can not be changed into passive because it does not have any object. It would not be acceptable if was determined translated to ditekad (it has no meaning in TL). Unlike the first example, the second example is to active sentences in the TL. The form of the passive sentences in the SL is still the same as the findings which have been described above. Most of them are in simple past tense to be + past participle and some of them are using modal + past participle. The different is just on the construction of the result of the translation in the TL. They become active sentences in TL which are indicated by the addition of prefix me- and ber-.

It must be done in order to get the closest meaning and natural equivalent meaning of the SL to the TL. There are 41 sentences found. The followings are some of the examples.

\section{$T L$}

Jacob bertekad untuk ikut bersama kami

Aku benar-benar kecewa Alice tidak memaksamu melihat ke cermin

translated to memaksa with the attachment of prefix mem-. It becomes a transitif verb that has an object.

The second objective of this study is finding the translation shift that occurs from the English passive sentences into Indonesian. According to Catford (1965) Translation shifts are departure from formal correspondence in the process of going from SL to the TL. Formal correspondence means 'any TL category (unit, class, structure ...) which can be said to occupy, as nearly as possible, the "same" place in the "economy" of the TL as the given SL category occupies in the SL" (Catford, 1965). The examples of shifts based on Catford's theory are change in word class / part of speech, change in the rank of unit (word to phrase, word to clause, phrase to clause, and vice 
versa), change in the word order, etc. He distinguishes translation shift into two types. They are level shift and category shift. The level shift is something which is expressed by grammar in one language and lexis in another. The category shift consists of structural shift, class shift, unit shift/rank shift, and intra-system shift. Baseds on this explanation, translation shifts may occur when the equivalent of a specific SL element is in different TL level or category.

The type of shift found in the novels is level shift. As stated above, the level shift is a shift that occurs from the grammar level to the lexis or vice versa. Most of the translation results are from passive to passive. The grammar or the constructions of the English passive sentences found in the SL are to be + past participle, had + been + past participle, and modal + be + past participle. Those grammars are simply stranslated into lexis in Indonesian language (SL). Lexis (vocabulary) refers

\section{$S L$}

\section{I am disappointed that Alice didn't} make sure you were forced to look in a mirror

The passive construction in the SL is subject (you) + to be (were) + past participle (forced). The same construction of this passive sentence in SL is subject $($ kamu $)+$ verb (dipaksa). The result of the translation above indicates the changing of word sequence into an active arrangement. The arragement becomes subject (Alice) + verb (memaksa) + object (kamu). The subject in the SL becomes object in the TL. to single words or sets of words that have a specific meaning, for example: orange, wake up, get up, etc. Based on the data found, the construction of passive sentence in TL is translated into word with different prefix and confix. The prefixs are $d i$ - (for a deliberate action) and ter- (for an accidental action). The confix is di-kan. Those prefixs (di-, ter-) and confix (dikan) are the characteristic of Indonesian passive verbs.

The second type of shift found in the data is structural shift. The structural shift refers to the changing of words sequence in a sentence. Different arrangement of words form SL to TL must be made to get the equivalent meaning. In some cases, it is done due to the translator himself who wants to follow a certain translation style. The changing of word sequence is from passive construction in the SL into active construction in the TL. One of the data is in the following.

\section{$T L$}

Aku benar-benar kecewa Alice tidak memaksamu melihat ke cermin

\section{CONCLUSION}

The analysis of English passive sentences translated into Indonesian answers the two objectives of this study. First, it is found that there are two types of translations: passive to passive and passive to active. Most of the English passive sentences are translated into passive sentences in Indonesian language. The construction of Indonesian passive sentences found in the novel is indicated by the addition of prefix $d i$ - and ter-, and also confix di- -kan. Here, the translator must be able to use the correct prefix by 
understanding the meaning of the action verb after the addition of a particular prefix. There are also translations from passive into active in the TL. The active construction in the TL is indicated by the addition of prefix ber- or me- to the action verb. The second finding is related with the type of translation shift that applied by the translator. There are level shift and structural shift. The passive sentence which is expressed by grammar in the SL becomes lexis in the TL (level shift). The structural shift can be seen when the passive construction in the SL becomes active construction in the TL.

\section{BIBLIOGRAPHY}

Alwi, Hasan; Lapoliwa, Hans; Darmowidjojo, S. (2008). Tata Bahasa Baku Bahasa Indonesia (Edisi Ketiga) (3rd ed.). Balai Pustaka.

Baker, Mona. (1998). Routledge Encyclopedia of Translation Studies. Routledge.

Bell. Roger. (1991). Translation and Translating: Theory and Practice. Longman Inc.

Brown, G. Samuelsson. (2012). A Practiocal Guide for Translators (4th Ed). Multilingual Matters Ltd.

Catford, J. G. (1965). A Linguistic Theory of Translation: An Essay in Applied Linguistics. Oxford University Press.

Hatim, Basil; Munday, Jeremy. (2019). Translation An Advanced Resource Book for Students (2nd Ed). Routledge.

Kamayana, I. G. N. P. (2015). The Translation Equivalence of English Passive Sentences Into Indonesian. Litera Jurnal Bahasa Dan Sastra, 1(2), 174-194.

Meyer, S. (2008). Breaking Dawn. Little, Brown, and Company.

Meyer, S. (2009). Breaking Dawn Awal Yang Baru (M. D. Chresnayani
(Ed.)). Gramedia Pustaka Utama. Murphy, Raymond; Altman, R. (1992). Grammar in Use: Reference and Practice for Intermediate Students of English. Cambridge University Press.

Wikipedia. (2021). Bahasa Indonesia/Kalimat Pasif. Wiki Buku. https://id.wikibooks.org/wiki/Bahasa _Indonesia/Kalimat_Pasif 